\title{
Freedom and responsibility as key elements of sustainable development of education
}

\author{
Valentina Remizova ${ }^{1, *}$, Tatyana Nesterova ${ }^{1,}$, and Irina Moiseeva ${ }^{2}$ \\ ${ }^{1}$ Plekhanov Russian University of Economics (Orenburg branch), 460000 Orenburg, Russia \\ ${ }^{2}$ Orenburg State University, Department of Romance Philology and Methods of Teaching French, \\ 460018 Orenburg, Russia
}

\begin{abstract}
The paper reveals the future teachers' attitude towards freedom and responsibility in the context of sustainable development of education. Sustainable development seems to be impossible without the new generation of free, dignified, respectful, and responsible individuals. Freedom and responsibility are outlined from a pedagogical point of view. The concepts under study are considered to be of great significance for child's development. The information obtained during the survey and questionnaire conducted with first-year students of the pedagogical university indicates that future teachers do not yet have sufficient experience to correlate adequately the possibility of revealing school students' freedom and the need to be in charge of the behavior, actions and thoughts of their own. University students believe that school students generally take responsibility for completing individual assignments rather than common ones. Future teachers do not think that school students' attitude towards education is responsible and trustworthy, would-be teachers doubt that school students are able to manifest freedom and responsibility to full extent. The empirical data drive to the conclusion that it is necessary to change future teachers' attitude towards freedom and responsibility in their pedagogical activities. Future teachers are advised to change their attitude to freedom and responsibility in their activities.
\end{abstract}

\section{Introduction}

Now we are entering the 2030 Agenda decade initiated by the United Nations Organization and researches connected with education for sustainable development are considered to be of paramount importance. Education plays the key role within the process of sustainable development [1].

It has been investigated that Target 4.7 on the 17 Sustainable Development Goals does not stand all by its own; otherwise it is strongly interwoven with other SD goals dealing with eradiating poverty, decent work, sustainable production and consumption, gender inequality, etc. [2]. Sustainable development embraces both society and education, so the classroom is viewed as social, organizational and community environments [3]. Whole-

\footnotetext{
* Corresponding author: very-valentina@list.ru
} 
institution approaches take into consideration all forms of education - formal, non-formal, and informal - to strengthen sustainable development of education [4].

In today's digitally organised world the idea to understand sustainable development of education as a participatory process of education and technology knowledge development seems to be a sound one [5]. Different educational issues including methodologies, transformative teaching and learning are discussed to work out better content of ESD in the future practice of teaching [6]. As teachers' training is of special significance in ESD the student-teachers' attitude towards sustainable development is worth to be studied [7].

Sustainable development seems to be impossible without the new generation of free, dignified, respectful, and responsible individuals. The teaching practice involves lots of aspects, and upbringing a person who feels both free and responsible in his/ her life and activities turns out to the main one in the way towards sustainable future.

This study touches upon the important theoretical and practical problem of identifying the manifested degree of freedom and responsibility in the context of pedagogical activities. The main prerequisites for the study of freedom and responsibility in the practice of education are social, economic and educational factors: firstly, the development of market relations led to a change in behavioral models and ethical principles; and secondly, the absence of concepts aimed at the development of such personal characteristics as freedom and responsibility in a modern school.

Currently, the problem of freedom and responsibility is considered from different points of view. The relationship between the freedom and responsibility in teachers' activities is highlighted by E. F. Khanova [8]. It is argued that the prerequisite for person's choice of an occupation, profession depends on person's freedom, freedom of choice; and professional responsibility is developed in the process of professional education. Freedom and responsibility as ethical categories are a dialectical unity, the basis for the development of individual's ethical principles. (A.V. Belikov, N. S. Shumilina) [9].

The continuous ethical development is identified as an important factor in the process of becoming a professional. It is established that the educational process at schools and universities contributes to the development of individual's professional and ethical development to a great extent. Different methods have been worked out for diagnosing person's professional and ethical development [10].

\section{Research methodology}

The purpose of this paper is to reveal future teachers' attitude towards freedom and responsibility. In connection with this goal, it was supposed to solve the following objectives:

- to clarify the concepts of freedom and responsibility from a pedagogical point of view;

- to identify the manifestation of freedom and responsibility in the context of the educational process.

First year students of the pedagogical university were chosen as a target group for studying. The research is based on reliable, effective and valid methods widely accepted in pedagogical analysis. They are literature review, study of pedagogical experience, observation, questioning, survey, generalization, systematization, methods of statistical data processing.

\section{Findings}

Freedom is one of the fundamental philosophical concepts. Since the ancient times of Plato and Aristotle up to the present day the problems of freedom have captured men of wisdom. 
At different times, J. Locke, K. Marx, J. P. Sartre, N. Berdyaev and other scholars notably contributed to the general understanding of the concept.

Following L.S. Vygotsky's, K.D. Ushinsky's, L.N. Tolstoy's, M. Montessori's and other thinkers belonging-to-the-humanistic-paradigm-of-education's ideas freedom is considered to be a pedagogical category. The literature review concerning the subject led us to the idea that freedom is the category reflecting the desire of an individual to conduct his life in accordance with his/ her own aspirations, desires, interests, goals, values. G. Leibniz argued that freedom depends on the reason: "The freer we are, the more we act in accordance with the reason, and the more enslaved, the more we indulge in passions" [11]. Modern scholars also point to the directly proportional interdependence of the manifested degree of freedom and the cognitive complexity of a person (E. F. Khanova) [8]. The representative of the philosophical and pedagogical thought of the early 20 -th century, S.I. Gessen interpreted freedom not as a primordial given to a person, but as a goal, a perspective of person's upbringing [12].

Today there is a point to speak about pedagogics of freedom that considers the student as a person who has the right to make choices.

In the paradigm of this concept, the term "freedom capacity" appears, which reveals itself in the ability of a student to independently build his educational route, choosing what, how and from whom to learn. Undoubtedly these processes start to be developed at the stage of secondary education, and higher education makes it possible to expand the possibilities of students' free choices. The efficiency of upbringing a free person is determined by the continuity of the activities of teachers who provide student with better conditions for the realization of people's natural need for autonomy. And here an individual school/ university student faces the problem of converting the resource of freedom into creativity, into creation, and not into arbitrariness and even self-destruction.

Freedom as an orientation towards good, towards the progress requires a completely clear hierarchy of values, person's movement towards self-realization, which is the highest stage of self-development. This orientation is fixed by the belief system, the linguistic picture of the world, well-built concepts of life success. The realities of modern life are such that the concept of success is directly related to the desire for wealth, fears of poverty.

Analysis of lexical representations of the concept of wealth and poverty in the speech of the youth shows that material values are emphasized, and all the signs associated with spiritual good, wealth are either neglected, or they tend to be expressed in monetary terms [13]. This pragmatism is a symbolic distinguishing feature of the modern society, which must be taken into account when working with young people.

If collective activities are not initiated in students' teams and groups by students themselves, but done according to external formal instructions, such activities cannot be associated with free creative work. The new economic reality shows a new attitude towards freedom: labor must be paid; otherwise the principle of justice is violated. All the motivators designed for the rigid authoritarian system do not work any longer. And new unifying attitudes based on enthusiasm, mutual assistance, the joy of collective creativity do not work or come into conflict with the reality. Therefore, so many difficulties arise in the youth environment when the real and formal signs of freedom clash.

The development of personal responsibility is associated with the practice of education. Responsibility is an attribute of interpersonal and intrasocial relations that characterizes the conscious implementation of the requirements that society imposes on an individual. Person's individual and social responsibility is distinguished. The external social and pedagogical conditions and individual's internal ethical and axiological state influence the realization of responsible person's attitude towards himself/ herself, other people, his/ her own actions, behavior, activities. In the humanistic concepts of the 20 -th century (M. M. 
Bakhtin, V. Frankl, E. Fromm), responsibility is associated with the qualities inherent of a mature personality.

Paradoxal thought as it may seem, freedom and responsibility do not stand in opposition, they are dialectically interacted. Freedom is outlined as the possibility of achieving a goal. Responsibility is associated with the need to take into account the real conditions for implementing individual goals. Highly developed person's responsibility and freedom reveal themselves in the personal behavioral autonomy, the ability to make decisions and control the situation in order to achieve goals.

Teacher's ability to be both free and responsible turns out to be an integral part of his/ her professional activities. Today's teaching practice requires that teachers are to make a choice at all stages of their pedagogical activities, from setting a goal to obtaining a result. The teacher is free to choose the means of accomplishing the set of goals and objectives, teaching methods, ways of interacting and communicating with students. If the teacher is demanding of himself/ herself, if he/ she sets high goals for himself/ herself, if he/ she is able to commensurate the idealized representation of the result of his activity with the real conditions, he makes the choice that is more conscious, reasonable and corresponding to reality.

While carrying out pedagogical activities based on overall cultural human values, the teacher apart from having inner freedom of his/ her own and being responsible for his/ her decisions must bring out the best in his/ her students.

In order to determine would-be teachers' attitude towards freedom and responsibility in pedagogical activities, such a method of pedagogical research as a survey was applied. First of all, first-year students who left school not long ago reported what tasks they had performed on their own at secondary school. Their reports were analyzed and a general list of such tasks was formed. Then the list of the tasks that school students could do on their own was given to future teachers - students of the pedagogical university.

As a result, university students chose only five tasks out of nine that school students could do independently: cleaning the classroom, preparing for the holiday, checking other students' notebooks and coming up with a school dress code.

The largest number of respondents agreed that students can independently assess the tasks done by their own (33\%), i.e. future teachers believe that school students are able to take full responsibility for self-assessment of their activities. At the same time, university students deny that school students are able to assess the activities of their class-mates adequately (for example, to check other students' notebooks). Future teachers doubt that school students are afraid of taking full responsibility for evaluating their mates.

Such a task as preparing a presentation on a proposed topic is considered by future teachers from the point of view of free and responsible implementation as quite feasible for school students $(20 \%)$. Indeed, students are free to choose the form of presentation, its style, visual and sound effects. The availability of technical means and information resources makes it possible to prepare a presentation efficiently and quickly, in due time.

In our opinion, the technical equipment in the schools, total availability of personal computers influenced the fact that future teachers could willingly entrust schoolchildren with the design of the classroom information board (17\%). Decorating the classroom information board, preparing for holidays, coming up with a school dress code are examples of creative activities, but only the design of the stand is recognized by future teachers as a task that students can fulfil with a great deal of freedom and responsibility.

University students believe that school students are able to give a lesson on their own $(17 \%)$. The lesson is a complex procedure of solving educational problems, and it requires careful preparation, adherence to a certain methodological concept. Perhaps, future teachers are not yet fully aware of the role of the lesson in the educational process, therefore they 
assign their functions to the students giving them a high degree of freedom and imposing a great deal of responsibility.

We take into account the reason mentioned above to explain the fact that the task to come up with assignments for the test was in the list of the tasks which school students can easily cope with. $13 \%$ of university students are sure of that.

To study would-be teachers' relation to the schoolchildren's manifestation of responsibility more closely the university students were asked to assess this quality using a five-point scale, with 5 points as the maximum score and 1 point as the minimum. The data obtained in the survey show that the first-year university students do not believe that school students' attitude towards responsibility to education deserve high estimation. None of university students rated the responsibility of school students a five, and only $7 \%$ gave this quality a rating of 4 points. On the contrary, schoolchildren's responsibility is assessed quite low (13\% assigned the value of 2 points and $14 \%$ gave only 1 point). A great number of respondents assessed the manifestation of school students' responsibility as average (a 3 point rating).

The information obtained during the survey and questionnaire indicates that future teachers do not have sufficient experience to correlate adequately the possibility of revealing school students' freedom and the need to be in charge of the behavior, actions and thoughts of their own. University students believe that school students generally take responsibility for completing individual assignments rather than common ones. Future teachers do not think that school students' attitude towards education is responsible and trustworthy.

\section{Discussion}

Sustainable development in education recognizes the coming generation as a community of people who are able to make free choices and be responsible for their actions, ideas and their implementation. Freedom and responsibility are part and parcel of people's mentality, pedagogical intercourse, professional activities, and human interrelations. We could not but agree with S.I. Gessen who believed that personal freedom stems from education, and the upbringing of freedom is the main goal of education [12].

Today in Russian classic pedagogical theory the ideas of P. F. Kapterov (1849-1922) about freedom in the practice of education are worth referring to [14]. P.F. Kapterov based on the postulate that freedom is the most important circumstance for child's development and proposed to give students the opportunity to choose school subjects in accordance with their interests, preferences, and even introduce new disciplines. P.F. Kapterov reckoned that schoolchildren could draw up a school schedule, choose books for extracurricular reading, and organize school holidays, excursions, and hikes [2]. We took into consideration P. F. Kapterov's understanding of freedom and responsibility while conducting our research.

The study of the pedagogical heritage of humanists allows stating the urgency of the problem of the ratio of teachers' level of freedom and responsibility and that of students. Freedom regulates the subjectivity and objectivity of individual student's position in interaction with information, a group, a teacher, the administration in the educational process. The free choice implementation at all stages of education requires that general cultural competencies and skills of introspection, self-analysis and self-knowledge should be well developed. 


\section{Conclusion}

The empirical data obtained during the research drive to the conclusion that it is necessary to change future teachers' attitude towards freedom and responsibility in their pedagogical activities.

Freedom and responsibility are shaped by activities where team and individual kinds of work are proportionally combined.

Thus, it can be stated that the study revealed future teachers' attitude to freedom and responsibility in education. University students do not highly appreciate school students' freedom and responsibility, would-be teachers doubt that school students are able to manifest freedom and responsibility to full extent. Future teachers themselves are advised to change their attitude to freedom and responsibility in their pedagogical activities.

\section{References}

1. J. Jakob, Ost. Religionspad. For., 28, 11 (2020)

2. K. Shulla, W. Leal, S. Lardjane, J.H. Sommer, C. Borgemeister, Int. J. of Sust. Dev. and W. Ecol., 27, 458 (2020)

3. L.G. Juarez-Hernandez, S. Tobon, G. Salas-Razo, A.E. Jeronimo-Cano, M.G. Martinez-Valdes, M+A-Rev. elect. de Med. Amb., 20, 54 (2019)

4. M. Tare, Tech.\& In., 21 (2020)

5. J. Bolmsten, M. E. Manuel, ETR\&D-Ed. Tech. Res. \& Dev., 68, 2705 (2020)

6. P. Glavic, Sust., 12 (2020)

7. A. Nousheen, S. A. Y. Zai, M. Waseem, S. A. Khan, J. of Clean. Pr., 250 (2020)

8. E. F. Khanova, University complex as a regional center of education, science and culture (OSU, Orenburg, 2924 (2016)

9. N. S. Shumilina, A.V. Belikov, Siber. Ped. J., 14 (2011)

10. N. S. Shumilina, Azim. of Sc. Res.: Ped. \& Ps., 9, 284 (2020)

11. G. V. Leibniz, Works collection in four volumes, 4, 351 (1989)

12. S. I. Gessen, Fundamentals of Pedagogy: Introduction to Applied Philosophy (1995) .

13. I. Moiseeva, V. Remizova, T. Nesterova, CILDIAH-2019 (SHS Web of Conferences), 69 (2019)

14. P. F. Kapterev, Selected pedagogical essays (1982) 